The molars, both upper and lower, in the South African fossil man-apes are unusually large, being exceeded only by Sivapithecus giganteus and by male gorillas. They differ, however, from those of gorilla, chimpanzee and other modern apes by certain easily recognizable peculiarities. In several respects their pattern has progressed towards the primitive human stage. It is not improbable that the great size of the third upper and lower molars was only a temporary phase preceding the reduction of these teeth in man.

The evidence from the Taungs infant is completely concordant with that of the Sterkfontein and Krom. draai adults, namely, that there lived in the upper Pleistocene of South Africa a group of small-brained man-apes that were derived from the widespread dryopithecine stock and were the less progressive cousins of man.

\title{
EIGHTH INTERNATIONAL CONGRESS OF REFRIGERATION
}

$\mathrm{P}$ LANS are being made to hold an international refrigeration congress at Cologne and Berlin during July 1-6, 1940. These congresses are held at intervals of about four years under the auspices of the International Institute of Refrigeration, which was set up by an international convention in 1920 and is supported by the majority of the nations.

After the Hague Congress in 1936, the scientific and technical side of the work of the International Institute of Refrigeration was reorganized and the control of that work entrusted to seven commissions, under a technical board composed of the presidents of the commissions dealing with various aspects of refrigeration. The reorganization became effective in 1938, when meetings of the commissions and technical board were convened in the rooms of the Royal Society. A one-day Conference on Refrigeration was also held following these meetings, and at this conference a number of papers were read which had been selected to embrace topics of especial interest to refrigerationistis.

On July 14-16 last, similar meetings were held at Baden Baden and Karlsruhe, Germany. At the meetings of the technical board, a draft programme for the 1940 Congress was outlined.
On July 15, a Conference on Refrigeration took place at the Technical University at Karlsruhe, which has a department dealing with the engineering and physical side of refrigeration. In the grounds of the University is situated the Reich Institute of Foodstuff Preservation which is under the Ministry of Agriculture.

At the Refrigeration Conference four papers were read. Georges Claude dealt with the production and utilization of krypton. $\mathrm{He}$ indicated the advantages of the use of krypton for filling incandescent lamps, and stated that the production must be a separate field of activity rather than a byproduct from liquid oxygen. G. Maiuri described machines working on the absorption principle and diffusing the refrigerant vapour in an inert gas. $\mathrm{He}$ stated that it is possible to attain temperatures below $-100^{\circ} \mathrm{C}$. Ezer Griffiths dealt with various forms of hygrometers adapted to meet special requirements, and with humidity control. R. Plank dealt with gir-conditioning in deep mines.

The meetings of the Technical Board were attended by representatives of various nationalities, and at the Refrigeration Conference there was a good attendance of German refrigerationists.

\section{THE CAUSATION OF APPENDICITIS}

A PPENDICITIS is an inflammation around the cacum, involving the vermiform appendage, and frequently associated with perforative ulceration. Previous to 1900 , the disease was generally described under the names 'typhlitis' and 'perityphlitis'. The modern term 'appendicitis' began to be used in America between 1890 and 1900, and as a cause of death it first appears in the Registrar-General's annual report for 1901 .

The immediate cause of appendicitis is a bacterial infection, but although the disease is a common one, the causes that predispose or precipitate an attack still remain but little understood, though stagnation of the intestinal contents in the appendix resulting in the formation of hard concretions is probably an important factor in many cases. There is a certain amount of information which suggests that habits of life, and in particular dietary habits, are of importance in predisposing to the disease.

In an endeavour to elucidate the causation of appendicitis, Dr. Natthew Young and Mr. W. T. Russell have surveyed the mortality statistics of Great Britain and of other countries and the statistics of certain hospitals, and their report is now published ("Appendicitis : A Statistical Study". Medical
Research Council, Special Rep. Series, No. 233. H.Mr. Stationery Office. 1s. net). The figures relating to the frequency of appendicitis confirm that it is very prevalent and that it has been on the increase in recent years. Another point brought out is that the mortality in the highest social class is at least two and a half times greater than in the poorest social class, although the majority of diseases, especially those involving bacterial action, are commoner among poorer people. A curious feature of the mortality rates from appendicitis in women is that the figures strongly indicate that the mortality is greater among single than among married women.

The suggestion has been made that the nature of the diet may have an influence in predisposing to appendicitis, either an excess of food or possibly certain types of food, and both of these factors are probably more common among the well-to-do. The taking of purgatives or laxatives is another cause suggested, and this practice is probably more common in the higher social class and among women. No data bearing on these factors were obtained, though it is significant that the mortality from appendicitis in females fell during the war years 1915-18, when food restrictions were imposed, and increased afterwards. 